\title{
Women, Violence, Sovereignty: "Rakshasa" Marriage by Capture in Modern Indian Political Thought
}

\author{
Luna Sabastian* \\ Centre of South Asian Studies, University of Cambridge \\ ${ }^{*}$ Corresponding author. E-mail: slks2@cam.ac.uk
}

Nineteenth-century colonial jurists, sociologists, and Indian nationalists revived the ancient Indian legal concept of rakshasa marriage by bride capture after vanquishing her kinsmen, which the Hindu "lawgiver" Manu condemned but permitted to the warrior caste alone. Only the Kshatriyas, India's designated sovereigns, could break patriarchal and brahmanical authority in this way. But rakshasa marriage was also identified with the demon Ravana, who abducted Sita in the epic Ramayana, and with Hindu nationalism's Muslim enemy. Preoccupied with the loss of kshatriyahood, Hindu nationalism uniquely premised sovereignty on the power to dispossess enemy Fathers of their women: from Bankim Chandra Chattopadhyay's celebration of epic hero Arjuna and Krishna's own rakshasa marriages, to the appropriation of this supposedly Muslim method by the architect of Hindutva, Vinayak Damodar Savarkar (1883-1967). Transcending the "sexual contract" in the Indian case, rakshasa marriage's association of bride capture and miscegenation with sovereignty sheds new light on gendered Partition violence, beyond brahmanical notions of (defiled) purity and honor.

Rakshasa is popularly known in India as a demonic, enemy race of Hindu mythology. ${ }^{1}$ Not commonly known is that the Sanskrit term doubles as a legal concept taken from the famous Manusmriti (Manava-Dharmashastra, or "Laws of Manu"), usually dated to the second century CE. According to Manu, the seventh of eight forms of marriage contract, universally "disapproved" yet permissible for the Kshatriya (or "warrior") caste alone, rakshasa is the "[m]arriage by seizure of a maiden by force from her house, while she weeps and calls for assistance, after her kinsmen and friends have been slain in battle or wounded, and their houses broken open," as rendered in John D. Mayne's influential translation of $1878 .^{2}$ In its first translation in the pioneering effort towards the codification of Gentoo Laws in 1776, rakshasa marriage is styled "Ràkhus, so called, when a Man marries the Daughter of another, whom he has conquered in War." ${ }^{3}$ Other texts within the ancient ethical and legal Dharmashastra genre similarly treated rakshasa, ${ }^{4}$ but it

\footnotetext{
${ }^{1}$ For this figure see Sheldon Pollock, "Rākșasas and Others," Indologica Taurinensia 13 (1985), 263-81.

${ }^{2}$ John D. Mayne, A Treatise on Hindu Law and Usage (Madras and London, 1878), 69, 66.

${ }^{3}$ Nathaniel Brassey Halhed, A Code of Gentoo Laws, or, Ordinations of the Pundits: From a Persian Translation, Made from the Original, Written in the Shanscrit Language (London, 1776), 48.

${ }^{4}$ P. R. Ganapathi Iyer, Hindu Law: A Treatise, book 1, General Principles and Marriage (Madras, 1915), 475. unrestricted re-use, distribution, and reproduction in any medium, provided the original work is properly cited.
} 
was the Dharmashastra attributed to Manu that was reified as the major, supposedly authoritative source of Anglo-Hindu personal law. An idiosyncratic colonial invention, the "personal law" of religious communities allowed Britons to rule Indians through the fig leaf of nonintervention in marriage, inheritance, caste, and religious matters. ${ }^{5}$ Yet having revived rakshasa marriage in a modern legal context in the first place, the British proceeded to criminalize it. Following the Indian Penal Code of 1860, a consensus of court cases, ${ }^{6}$ legal thinkers, Indian politicians, and political thinkers ${ }^{8}$ declared rakshasa an "obsolete" form of marriage, invoking this exact phrase with remarkable invariance throughout the nineteenth and twentieth centuries. ${ }^{9}$ Manu's legal definition of rakshasa marriage now constituted any of the criminal offenses of enticement, kidnapping or abduction, and rape, where applicable.

This article traces rakshasa marriage as an explicit concept of gendered conquest in Indian political thought. The conception of a distinctly Kshatriya-mode of marriage as generative of sovereignty developed in tension with the brahmanization of marriage that was contemporaneously codified into Hindu law. ${ }^{10}$ Its significance transcended the law and India. Rakshasa marriage entered global sociological and political theorizing in the nineteenth century as the primitive "marriage by capture." It was identified with "exogamy" and the capture of women as booty in war. In rakshasa marriage, the Kshatriya's triumphant exogamy displaces the Brahmin's endogamous purity: a deliberate crime against law, patriarchy, and caste.

Historians of India have remained unconvinced that the modern state confined women to a "private sphere" set against and excluded from a "public sphere" of politics, which motivates feminist projects of recovering women's voices. ${ }^{11}$ The reason is that from its very outset, British rule in India targeted the supposedly private sphere of women in order to push into Indian society (beginning with the Abolition of Sati Act of 1829 and the Widow Remarriage Act of 1856). ${ }^{12}$ Women and the home in turn became the site of a native potentiality for

\footnotetext{
${ }^{5}$ Julia Stephens, Governing Islam: Law, Empire, and Secularism in Modern South Asia (Cambridge, 2018), 23, 29-30, 33, 37-8, 40-44, 52.

${ }^{6}$ Maharaja of Kolhapur v. Sundaram Ayyar (1925) ILR 68 Mad 1, 935, at https://indiankanoon.org/doc/ 1363504 .

${ }^{7}$ Priyanath Sen, The General Principles of Hindu Jurisprudence, Tagore Law Lectures, 1909 ([Calcutta], 1918), 268.

${ }^{8}$ Hari Singh Gour, The Hindu Code: Being a Codified Statement of Hindu Law with Commentary Thereon (Calcutta, 1919), 225.

${ }^{9}$ This standard most likely derived from Mayne, A Treatise on Hindu Law, 69.

${ }^{10}$ For the latter see Samita Sen, "Offences against Marriage: Negotiating Custom in Colonial Bengal," in Mary E. John and Janaki Nair, eds., A Question of Silence? The Sexual Economics of Modern India (New Delhi, 1998), 77-110.

${ }^{11}$ See Anna Becker, "Gender in the History of Early Modern Political Thought," Historical Journal 60/4 (2017), 843-5.

${ }^{12}$ See Veena Talwar Oldenburg, Dowry Murder: The Imperial Origins of a Cultural Crime (New York, 2002), 11, 48; Flavia Agnes, Law and Gender Inequality: The Politics of Women's Rights in India (Oxford, 1999), 46-7; Lata Mani, Contentious Traditions: The Debate on Sati in Colonial India (Berkeley, 1998). See also Gayatri Chakravorty Spivak's iconic framing of the British civilizing mission as "white men are saving brown women from brown men," in "Can the Subaltern Speak? Speculations on Widow Sacrifice," Wedge 7/8 (1985), 120-30, at 121. For a comparative perspective on British imperial sovereignty in connection to legislation on "native" women's sexuality see Antoinette Burton, "Accounting
} 
sovereignty, which colonialism excluded from the "public" business of politics. ${ }^{13}$ That sovereignty should be gendered, usually as male, and that women or feminized bodies should be fundamental to its operations, speaks from newer work on the nexus of colonialism, sexuality, and race, ${ }^{14}$ and (still marginal) feminist histories of political thought alike. ${ }^{15}$ If these accounts are concerned with the gendered foundations of sovereignty either established or establishing, this article is concerned with their breakdown. To be sure, gendered consequences of the breakdown of a gendered sovereign order are well theorized in the context of war and genocide, where sexualized violence targets women as national or group symbol, ${ }^{16}$ battlefield, ${ }^{17}$ ethnomarker, ${ }^{18}$ booty, ${ }^{19}$ and womb. ${ }^{20}$ Uniquely, rakshasa marriage provides an explicit genealogy in the history of political thought linking war over sovereignty to the capture of enemy women. As such, rakshasa marriage contributes to the important work of historicizing (and exorcizing) the only universal, naturalseeming links between gender and power. ${ }^{21}$ Rakshasa sheds light on the process of naturalization itself as in nineteenth-century social theorizing; it designated no less than the state of nature. This article will be of interest to scholars of Hindu nationalism and communalism in India; the social and sexual contract in and beyond South Asia; and the historiographies of gender, sovereign violence, and global political thought.

Rakshasa marriage designates the dissolution of father's power and of the existing moral and sovereign order. Usefully in this context, Schmitt and Agamben

for Colonial Legal Personhood: New Intersectional Histories from the British Empire," Law and History Review 38/1 (2020), 143-50, at 147.

${ }^{13}$ See Tanika Sarkar's improvement, in Hindu Wife, Hindu Nation: Community, Religion, and Cultural Nationalism (New Delhi, 2001), 39-41, of Partha Chatterjee's famous argument about the public (outer, colonial)/private (inner, Indian) divide, in Nationalist Thought and the Colonial World: A Derivative Discourse? (London, 1986); see also Rosalind O'Hanlon, "Issues of Widowhood: Gender and Resistance in Colonial Western India," in Douglas E. Haynes and Gyan Prakash, eds., Contesting Power: Resistance and Everyday Social Relations in South Asia (Delhi, 1991), 72-9.

${ }^{14}$ See, inter alia, Mrinalini Sinha, "Giving Masculinity a History: Some Contributions from the Historiography of Colonial India," Gender \& History 11/ 3 (1999), 445-60; Ashis Nandy, The Intimate Enemy: Loss and Recovery of Self under Colonialism (New Delhi, 1983); Ann Laura Stoler, Race and the Education of Desire: Foucault's History of Sexuality and the Colonial Order of Things (Durham, NC, 1995); Stoler, Carnal Knowledge and Imperial Power: Race and the Intimate in Colonial Rule (Berkeley, 2002); Anne McClintock, Imperial Leather: Race, Gender, and Sexuality in the Colonial Contest (London, 1995).

${ }^{15}$ Besides Carole Pateman's classic, The Sexual Contract (Stanford, 1988); see, for example, Joan W. Scott, "Gender: A Useful Category of Historical Analysis," American Historical Review 91/5 (1986), 1053-75; Mary Laura Severance, "Sex and the Social Contract," English Literary History 67/2 (2000), 453-513; Nancy J. Hirschmann, "Hobbes on the Family," in Al P. Martinich and Kinch Hoekstra, eds., The Oxford Handbook of Hobbes (Oxford, 2016), 242-63; Anna Becker, Gendering the Renaissance Commonwealth (Cambridge, 2020), 195-9.

${ }^{16}$ See, seminally, Nira Yuval-Davis, Gender and Nation (London, 1997).

${ }^{17}$ See Susan Brownmiller, Against Our Will: Men, Women and Rape (New York, 1975).

${ }^{18}$ Darius M. Rejali, “After Feminist Analyses of Bosnian Violence," in Lois Ann Lorentzen and Jennifer E. Turpin, eds., The Women and War Reader (New York, 1998), 30-32.

${ }^{19}$ See Roland Littlewood, “Military Rape," Anthropology Today 13/2 (1997), 11-12.

${ }^{20}$ See Siobhán K. Fisher, "Occupation of the Womb: Forced Impregnation as Genocide," Duke Law Journal 46/1 (1996), 91-133.

${ }^{21}$ See Becker, “Gender in the History of Early Modern Political Thought," 849; Scott, “Gender,” 1073. 
define sovereign power through its ability to transcend the legal order. ${ }^{22}$ The sovereign power of (violent) transgression against the gendered sovereign order, usually in the interest of maintaining this order, ${ }^{23}$ lies with the white colonial and slave master, ${ }^{24}$ with dominant groups, and in India with the upper castes. Recent scholarship has shown how Brahmin supremacy is maintained through policing upper-caste women's sexuality, while forcing access to Dalit (untouchable) women's sexuality. ${ }^{25}$ An economy of sexual assault down the descending hierarchy of caste doubles the sexual economy of caste as rooted in marriage, kinship, and exchange. $^{26}$ These insights into the gender-caste nexus should serve to cast doubt on framings of intercommunal (Hindu-Muslim) abductions and rapes as attacks on the enemy community's purity, which fail to convince where rapes pollute the perpetrator along with the victim. Rakshasa marriage in fact allows us to radically reconsider the gendered nature of communal violence especially during the Indian Partition, beyond ubiquitous brahmanical notions of purity, endogamy, patriarchal exchange, and the control of female sexuality as the vestige of community purity and "honor" (izzat). ${ }^{27}$ In the event of exception in $1947,{ }^{28}$ rakshasa marriage was deliberately employed to break the existing gendered moral and sovereign order. As rumor of rapes and abductions marked the beginning of the

\footnotetext{
${ }^{22}$ Carl Schmitt, Politische Theorie: Vier Kapitel zur Lehre von der Souveränität (Munich, 1922); Giorgio Agamben, Homo Sacer: Sovereign Power and Bare Life, trans. Daniel Heller-Roazen (Stanford, 1998; first published 1995).

${ }^{23}$ Saul Newman, "Terror, Sovereignty and Law: On the Politics of Violence," German Law Journal 5/5 (2004), 569-84, at 572.

${ }^{24}$ See, recently, Rachel A. Feinstein, When Rape Was Legal: The Untold History of Sexual Violence during Slavery (New York, 2018).

${ }^{25}$ See Anupama Rao, "Understanding Sirasgaon: Notes towards Conceptualising the Role of Law, Caste and Gender in a Case of 'Atrocity'," in Rao, ed., Gender and Caste (London, 2005; first published 2003), 296-309, at 297; Rao, The Caste Question: Dalits and the Politics of Modern India (Berkeley, 2009), 2335; Chakravarti, Gendering Caste, 30-32, 152-5; Vasanth Kannabiran and Kalpana Kannabiran, "Caste and Gender: Understanding the Dynamics of Power and Violence," in Rao, Gender \& Caste, 249-60, at 254-5; Prem Chowdhry, "Enforcing Cultural Codes: Gender and Violence in Northern India," in Janaki Nair and Mary E. John, eds., A Question of Silence: The Sexual Economies of Modern India (London, 2000; first published 1998), 332-67; Pratishka Baxi, Public Secrets of Law: Rape Trials in India (New Delhi, 2014), 36-40, 293-4, 313.

${ }^{26}$ Rao, Caste Question, 233, 235.

${ }^{27}$ For the brahmanical notion of caste as defined by purity/pollution see, paradigmatically, Louis Dumont, Homo Hierarchicus: The Caste System and Its Implications, complete rev. English edn (Chicago, 1980; first published 1966). See this axiom at work in explanations of communal violence in, inter alia, Megha Kumar, Communalism and Sexual Violence in India: The Politics of Gender, Ethnicity and Conflict (London, 2016), 13; Yasmin Khan, The Great Partition: The Making of India and Pakistan (New Haven, 2007), 133-4; Tanika Sarkar, "Semiotics of Terror: Muslim Children and Women in Hindu Rashtra," Economic and Political Weekly 37/28 (2002), 2872-6, at 2875; Urvashi Butalia, The Other Side of Silence: Voices from the Partition of India (New Delhi, 1998), 210; Charu Gupta, Sexuality, Obscenity, Community: Women, Muslims and the Hindu Public in Colonial India (Delhi, 2001); Purushottam Agarwal, "Surat, Savarkar and Draupadi: Legitimising Rape as a Political Weapon," in Tanika Sarkar and Urvashi Butalia, eds., Women and the Hindu Right: A Collection of Essays (New Delhi, 1995), 29-57, at 38; Chakravarti, Gendering Caste, 26-33, 142-4.

${ }^{28}$ Shruti Kapila, "A History of Violence," in Kapila and Faisal Devji, eds., Political Thought in Action (Cambridge, 2013), 177-99, at 196.
} 
exception in towns and villages across India, ${ }^{29}$ rakshasa marriage simultaneously announced that sovereignty was in contestation and served as means to decide the contest.

The logic of rakshasa marriage was deeply embedded in Hindu nationalism, or Hindutva, by the time of the Partition that witnessed mass slaughter and mass migration along with women's abduction, rape, forcible marriage, conversion, and suicide. Working abductions that crossed religious lines into the logic of a fullblown civil war between Hindus (including Sikhs) and Muslims, Hindu nationalists endorsed rakshasa marriage to mirror purported Muslim actions that were coveted as well as reviled. For, by the 1920s, the Muslim enemy stood accused of forcefully abducting and converting Hindu women, ${ }^{30}$ likely drawing on an older Indian Muslim controversy over the Quranic legality of taking war captives, and female slaves as concubines. ${ }^{31}$ Hindutva's architect, Vinayak Damodar Savarkar (18831967), unambiguously made rakshasa marriage with Muslim women the key to vanquishing the Muslim enemy. In so doing, Savarkar asked Hindu nationalists to adopt a persona that combined the Hindu Kshatriya and the enemy Muslim "Rakshasa," or demon, no less. Whereas we know that women's protection from the rapist/abductor who is invariably cast as "other" justifies violent, reactionary projects in the past and present, ${ }^{32}$ this article uniquely illuminates the ideological effort involved in transforming the self into the other as sovereign. To vanquish the Muslim enemy, Hindus had to become like them by stealing women and breaking caste.

\section{Capturing brides, breaking father's power}

Criminalized in 1860, rakshasa marriage nevertheless survived in Indian legal discourse. Textbooks continued to cite it, ${ }^{33}$ and aspiring Indian civil servants and legal practitioners continued to scribble it into their notebooks and revise it, as did one British law student in the late nineteenth century who later became an Indian High Court judge. ${ }^{34}$ This state of affairs continued into the twentieth century, ${ }^{35}$ and

\footnotetext{
${ }^{29}$ Khan, The Great Partition, 133-5.

${ }^{30}$ Gupta, Sexuality, Obscenity, Community, 246-8; Shashi Joshi and Bhagwan Josh, Struggle for Hegemony in India 1920-47, 3 vols. (New Delhi, 1992), 3: 206-14; Pradip Kumar Datta, “Abductions' and the Constellation of a Hindu Communal Bloc in Bengal of the 1920s," Studies in History 14/1 (1998), 37-88, at 37-8.

${ }^{31}$ See Avril A. Powell, "Indian Muslim Modernists and the Issue of Slavery in Islam," in Indrani Chatterjee and Richard M. Eaton, eds., Slavery and South Asian History (Bloomington, 2006), 262-86, at 268-9, 278-9.

${ }^{32}$ See Papiya Ghosh, "The Virile and the Chaste in Community and Nation Making: Bihar 1920's to 1940's," Social Scientist 22/1-2 (1994), 80-94; Ratna Kapur, "Gender, Sovereignty and the Rise of a Sexual Security Regime in International Law and Postcolonial India," Melbourne Journal of International Law 14/2 (2014), 1-30.

${ }^{33}$ For example, Raymond West and Georg Bühler, eds., A Digest of the Hindu Law of Inheritance and Partition, from the Replies of the Sâstris in the Several Courts of the Bombay Presidency: With Introductions, Notes, and an Appendix, 2nd edn (Bombay, 1878), 224, 226, 432.

34"Six Notebooks on Legal Terms and Situations, Petitions, the Indian Penal Code, Hindu and Muslim Law, and Language," 1891-1900, MSS Eur 523/41, Papers of Sir Thomas Stewart Macpherson (1876-1949), British Library, London, 1:46v-47r.

${ }^{35}$ For example, Jagannanth Raghunath Gharpure, Hindu Law (Bombay, 1905), 33-4; Ernest John Trevelyan, Hindu Family Law: As Administered in British India (London, 1908), 51.
} 
remains unbroken in India's postcolonial history. ${ }^{36}$ Yet rakshasa marriage was more than an academic exercise in colonial India. It continued to have real legal effect, in matters of inheritance where a wife's personal property (stridhan) devolved on her own kin instead of her husband's only if her wedding took one of Manu's four "disapproved" forms. ${ }^{37}$ In such case she failed to become one with her husband's body and legal personhood. ${ }^{38}$ Rakshasa marriage even mitigated the criminal offense of rape, as in a court case in Nagpur in 1927 where the recognition of a supposed tribal "custom" of marriage initiated through abduction and rape weighed against standardized, brahmanical Anglo-Hindu law and, ultimately, against fourteen-year-old Phula, who had refused to marry her rapist. ${ }^{39}$ Finally, rakshasa marriage continues to be invoked in contemporary India, where family opposition muddles the line between nonconsensual abduction and socially transgressive elopement. ${ }^{40}$

Perhaps most striking about the conceptual history of rakshasa marriage in the almost hundred years from its criminalization to the early years of Indian independence is its simultaneous ubiquity and silencing. Attempts were made to domesticate rakshasa in line with what historian Samita Sen calls the "legal and

\footnotetext{
${ }^{36}$ T. P. Gopalakrishnan, Hindu Marriage Law: Containing Exhaustive Commentaries on the Hindu Marriage Act, 25 of 1955, and a Detailed Exposition of Hindu Marriage Law from Earliest Times to Date: With Useful Appendices (Allahabad, 1957), 29.

${ }^{37}$ Gooroodass Banerjee, The Hindu Law of Marriage and Stridhana (Being the Tagore Law Lectures for 1878), 2nd, revised edn (Calcutta, 1896; first published 1879), 364. For the application of this maxim in a court room see Mt. Kishan Dei v. Sheo Paltan (1926) AIR Allahabad 1. Cf. Rachel Sturman, The Government of Social Life in Colonial India: Liberalism, Religious Law, and Women's Rights (Cambridge, 2012), 169-70, who assumes Manu's unapproved forms of marriage-she exclusively treats asura or bride purchase-to have become marginalized to the point of becoming "unintelligible as such" by the beginning of the twentieth century.

${ }^{38}$ See Flavia Agnes, "Introduction," in Flavia Agnes, Sudhir Chandra, and Monmayee Basu, eds., Women and Law in India: An Omnibus Comprising Flavia Agnes, Law and Gender Inequality: The Politics of Women's Rights in India, Sudhir Chandra, Enslaved Daughters: Colonialism, Law and Women's Rights, Monmayee Basu, Hindu Women and Marriage Law: From Sacrament to Contract (Oxford, 2004), ix-xlv, at $\mathrm{xv}$.

${ }^{39}$ Garab Singh Gond v. Emperor (1927) AIR Nagpur 279, at 280; cf. the discussion of this case in J. Duncan M. Derrett, The Death of a Marriage Law: Epitaph for the Rishis (New Delhi, 1978), 53-4. For a similar use of a cultural-relativist argument to mitigate rape charges in a US court see Anne Phillips, Multiculturalism without Culture (Princeton, 2007), 75. For a reverse example of codified marriage law superseding an alleged tribal "custom" of "Bhagoriya marriage" by abduction followed by intercourse and subsequent payment of bride price in postcolonial India see Nivedita Menon, "Embodying the Self: Feminism, Violence and the Law," in Partha Chatterjee and Pradeep Jeganathan, eds., Community, Gender and Violence (London, 2000), 66-105, at 79-80. For an invented "custom" of marriage by capture resulting in abduction and forced marriage outside India see Cynthia Werner, "Bride Abduction in Post-Soviet Central Asia: Marking a Shift towards Patriarchy through Local Discourses of Shame and Tradition," Journal of the Royal Anthropological Institute 15/2 (2009), 314-31. I am grateful to Sagnik Dutta and David Sneath for pointing me to these cases.

${ }^{40}$ Perveez Mody, "Kidnapping, Elopement and Abduction: An Ethnography of Love-Marriage in India," in Franscesca Orsini, ed., Love in South Asia: A Cultural History (Cambridge, 2006), 331-44, at 332; see also Pratiksha Baxi, Public Secrets of Law: Rape Trials in India (New Delhi, 2014), 244-52; Srimati Basu, The Trouble with Marriage: Feminists Confront Law and Violence in India (Oakland, 2015), 169-70; Uma Chakravarti, Gendering Caste: Through a Feminist Lens (Calcutta, 2003), 127, 144-51; Veena Das, "Sexual Violence, Discursive Formations and the State," Economic and Political Weekly 31/35-7 (1996), 2411-23, at 2416 .
} 
ritual brahmanisation of marriage." 41 This was where it, like the approved forms, was held to become legally binding only with the subsequent performance of the brahmanical marriage rites (especially the saptapadi or "seven steps"), rather than with the prior acts of abduction and sex. ${ }^{42}$ Invoking the legal concept of "consummation," sex was contentious even beyond its forced or illicit forms, as Indian jurists disagreed over whether it was the marriage ceremony, usually celebrated in childhood, or consummation celebrated at puberty that established Hindu marriage. Rejecting that sex legally constituted marriage, scholars Priyanath Sen and Pandurang Vaman Kane opined, in 1909 and 1941, that for the ancient Hindu lawgivers, the "wronged" girl would have remained legally a "virgin," and as such eligible for proper marriage. ${ }^{43}$ Commentators such as P. R. Ganapathi Iyer, an advocate at Madras's High Court, in 1915, invoked British alongside Manu's contract law to argue that force or fraud voided all contracts, including that of marriage. ${ }^{44}$ Rakshasa marriage, which arose from force, could be no marriage.

Another popular strategy of silencing rakshasa was its conflation with gandharva marriage, the sixth and likewise disreputable form of marriage that Manu nevertheless permitted to Kshatriyas. This was based on mutual attraction- "love marriage" in today's parlance. For example, colonial courts largely recognized the supposedly customary "dagger marriages" (khanda lagan, or katar marriage) of Rajputs, Rajahs, and Zamindars who pretended to Kshatriya status, as a valid (albeit inferior) marriage rather than concubinage, contracted with slaves and women of lower class and caste. ${ }^{45}$ While an early colonial account of a sword representing the groom at a Maratha wedding ceremony interpreted this as a ritualized way around the prohibition of intercaste marriage, ${ }^{46}$ subsequent legal discussion exaggerated the presence of the sword into an emblem of Kshatriya power and sovereignty wielded over an inferior wife. Jurists nevertheless identified the ritual with gandharva rather than rakshasa marriage. ${ }^{47}$ Rakshasa's erasure was final and complete where only the gandharva form appeared as historically permissible to Kshatriyas. ${ }^{48}$ A third strategy was implicit reference, an example being Rai Bahadur Pandit Kanhaiya Lal, a retired High Court judge who served as member of the Age of Consent Committee that paved the way for the 1929 Child Marriage Restraint

\footnotetext{
${ }^{41}$ Sen, "Offences against Marriage," 82.

${ }^{42}$ Ganapathi Iyer, Hindu Law, 479, 490; Sen, General Principles, 267.

${ }^{43}$ Sen, General Principles, 270; Pandurang Vaman Kane, History of Dharmasastra (Ancient and Mediaeval, Religious and Civil Law), 5 vols. (Poona, 1941), 2: part 1, 520.

${ }^{44}$ Ganapathi Iyer, Hindu Law, 399-403.

${ }^{45}$ See Indrani Chatterjee, "Introduction," in Chatterjee, ed., Unfamiliar Relations: Family and History in South Asia (New Brunswick, 2004), 3-45, at 12; Ganapathi Iyer, Hindu Law, 491. The decisive legal ruling was Ramasami Kamaya Naik v. Sundaralingasami Kamaya Naik (1894) ILR 17 Mad 422; Maharaja of Kolhapur v. Sundaram Ayyar (1925) ILR 68 Mad 1; Pandurang Vaman Kane, University of Bombay Sir Lullabhai A. Shah Lectures, 1944 on: Hindu Customs and Modern Law (Bombay, 1950), 92. Dagger marriages were no longer legally recognized after 1933. Gour, The Hindu Code, 120.

${ }^{46} \mathrm{John}$ Malcolm, A Memoir of Central India: Including Malawa, and Adjoining Provinces (Cambridge, 2011; first published 1823), 158.

${ }^{47}$ Sripati Roy, Customs and Customary Law in British India, Tagore Law Lectures 1908 (Calcutta, 1911), 287; Maharaja of Kolhapur v. Sundaram Ayyar (1925) ILR 68 Mad 1.

${ }^{48}$ V. S. Srinivasa Sastri, Marriage after Puberty According to the Hindu Sastras (Madras, 1906), 70-71.
} 
Act. ${ }^{49}$ He invoked the concept to argue for an exception to any legal age of consent, which would allow a "marriage in the disapproved form"-a seduction or worseto be solemnized by a subsequent marriage in the girls' own interest. ${ }^{50}$ Yet only comparison with the cited legal source makes the reference to rakshasa marriage overt. $^{51}$ Rakshasa marriage embarrassed and offended, but its true significance was that it seduced the nationalist imagination. It did so because it completely unshackled the Kshatriya idiom from brahmanical, legal, and moral restraint.

Rakshasa marriage came to designate an idiom of sovereignty in the political grammar of nationalist India. More precisely, it became a cypher for Hindu men's assumption of sovereignty through an act of gendered violence. This was sovereignty by “'acquisition,' specifically conquest," as Thomas Hobbes would have it. ${ }^{52}$ What Nancy Hirschmann's feminist reading in particular asserts of Hobbes's war of all against all in the state of nature strikingly resembles what nineteenthcentury thinkers drawing on rakshasa marriage, like the banker, archaeologist, and Darwin supporter John Lubbock (1834-1913), have asserted of the primitive war of enemy groups: that it is the act of choosing to leave the female captive, whom one might have killed, alive that conditions-in cruder versions, establishes-male dominion. ${ }^{53}$ The decisive difference between these accounts of humanity's origin in war is that where Hobbes viewed individuals, theorists of rakshasa marriage viewed social groups (clans or tribes) as the combatants and basic units of human society. While Hobbes's war is indiscriminate, only groups have a precise and thus real capacity for enmity. I will come back to this point. Rakshasa's overwhelming, if not necessary, condition was war. In 1916, one commentator in Calcutta's leading journal, the Modern Review, even went so far as to present rakshasa along with another two of Manu's disreputable marriage forms (paishacha, by rape of someone unconscious; and gandharva, by mutual desire) as the ancient Indian sages' solution to the very modern problem of "war babies." 54

In order to assume, through rakshasa marriage, the kind of power and indeed sovereignty that was based on sheer violence, one had to climb down the civilizational ladder to a previous, barbaric stage. It was to this conjectured stage that mid-nineteenth-century social theorists turned as ethnographic accounts of the aberrant sexual customs of "primitives" began to erode Victorian beliefs in the naturalness of patriarchal, monogamous marriage. For thinkers ranging from

\footnotetext{
${ }^{49}$ For the Child Marriage Restraint Act see Ishita Pande, Sex, Law and the Politics of Age: Child Marriage in India, 1891-1937 (Cambridge, 2020).

50"Report of the Age of Consent Committee, 1928-1929 (Calcutta: Government of India Central Publication Branch, 1929), Notes by Members: Note by Rai Bahadur Pandit Kanhaiya Lal, 20 June 1929, in File 1702 - Marriages in India: Age of Consent Committee Report, Indian Penal Code Amendment Act, 1925, Introduction of the Children's Protection Bill, IOR/L/PJ/6/1797, India Office Records and Private Papers, British Library, London, 224.

${ }^{51}$ The legal authority cited is Sen, General Principles, 269-70.

${ }^{52}$ Nancy J. Hirschmann, "Gordon Schochet on Hobbes, Gratitude, and Women," in Joanne H. Wright and Hirschmann, eds., Feminist Interpretations of Thomas Hobbes (University Park, 2012), 125-45, at 133.

${ }^{53}$ Ibid., 137, 141-2; see also Nancy J. Hirschmann, "Hobbes on the Family," in Al P. Martinich and Kinch Hoekstra, eds., The Oxford Handbook of Hobbes (Oxford, 2016), 242-63; John Lubbock, The Origin of Civilisation and the Primitive Condition of Man: Mental and Social Condition of Savages, American edn (New York, 1870), 71-2.

54“Foreign Periodicals," Modern Review 19/1 (1916), 96-103, at 102.
} 
the Swiss comparative jurist and misappropriated feminist milestone Johann Jakob Bachofen (1815-87 $)^{55}$ and anthropologists John Ferguson McLennan $(1827-81)^{56}$ and Lewis Henry Morgan $(1818-81)^{57}$ to Herbert Spencer, ${ }^{58}$ Engels, ${ }^{59}$ and Nietzsche, ${ }^{60}$ patriarchy now appeared as the last and perfected stage of human social, political, and legal evolution. Its least perfected stage was a pattern of wife capture between warring tribes, which only ended in the first dawn of civilization with primitive polyandry (female polygamy), followed by matriarchy, and finally patriarchy. ${ }^{61}$ In his Dissertations on Early Law and Custom (1883), the architect of liberal empire and theorist of India's failed evolution from kinship to contract, ${ }^{62}$ Sir Henry Sumner Maine (1822-1888), had to address but showed himself unconvinced by this newfangled theory of the origin of civilization in unregulated wife capture, which challenged his patriarchal theory of Ancient Law (1861). ${ }^{63}$ Manu's term rakshasa marriage served as both prototype and proof of this most ancient stage of "marriage by capture," as practiced by ancient and contemporary "primitives" alike. It could thus designate an ancient Germanic form of marriage in nineteenth-century tomes, ${ }^{64}$ and was observed among the ancient Semites and Bedouins of the Sinai in the twentieth century. ${ }^{65}$ There was certainly no escaping rakshasa marriage for sociologists interested in

\footnotetext{
${ }^{55}$ Johann Jakob Bachofen, Das Mutterrecht: Eine Untersuchung über die Gynaikokratie der alten Welt nach ihrer religiösen und rechtlichen Natur (Stuttgart, 1861).

${ }^{56}$ John Ferguson McLennan, Primitive Marriage: An Inquiry into the Origin of the Form of Capture in Marriage Ceremonies (Edinburgh, 1865).

${ }^{57}$ Lewis Henry Morgan, Systems of Consanguinity and Affinity of the Human Family (Washington, DC, 1871); Morgan, Ancient Society, or: Researches in the Lines of Human Progress from Savagery, through Barbarism to Civilization (New York, 1877).

${ }^{58}$ Herbert Spencer, The Principles of Sociology, 2nd edn, 3 vols. (London, 1877; first published 1874), 1: 640-59. See also Nancy L. Paxton, George Eliot and Herbert Spencer: Feminism, Evolutionism, and the Reconstruction of Gender (Princeton, 2014), 144.

${ }^{59}$ Peter J. Davies, Myth, Matriarchy and Modernity: Johann Jakob Bachofen in German Culture, 18601945 (Berlin, 2010), 66; Adam Kuper, The Reinvention of Primitive Society: Transformations of a Myth, 2nd edn (London, 2005; first published 1988), 79-81.

${ }^{60}$ It is debatable whether Nietzsche's Dionysian and Apollonian ideal required Bachofen. See Georg Dörr, Muttermythos und Herrschaftsmythos: Zur Dialektik der Aufklärung um die Jahrhundertwende bei den Kosmikern, Stefan George und in der Frankfurter Schule (Würzburg, 2007), 67-8.

${ }^{61}$ See Thomas R. Trautmann, Lewis Henry Morgan and the Invention of Kinship (Berkeley, 1987), 179204; George W. Stocking Jr, Victorian Anthropology (New York, 1991), 197-208; Kuper, Reinvention of Primitive Society, 42-5; Rosalind Coward, Patriarchal Precedents: Sexuality and Social Relations (London, 1983), 46-73; Andrew Lyons and Harriet D. Lyons, Irregular Connections: A History of Anthropology and Sexuality (Lincoln, 2004), 73-82; Durba Mitra, Indian Sex Life: Sexuality and the Colonial Origins of Modern Social Thought (Princeton, 2020), 133-57.

${ }^{62}$ See Karuna Mantena, Alibis of Empire: Henry Maine and the Ends of Liberal Imperialism (Princeton, 2010), esp. 81-2.

${ }^{63}$ Henry Sumner Maine, Dissertations on Early Law and Custom: Chiefly Selected from Lectures Delivered at Oxford (London, 1883), 195, 200, 204, 225-7. See Robert Redfield, "Maine's Ancient Law in the Light of Primitive Societies,” Western Political Quarterly 3/4 (1950), 574-89, at 575, 578.

${ }^{64}$ Lothar Dargun, Mutterrecht und Raubehe und ihre Reste im Germanischen Recht und Leben (Mother Right and Marriage by Capture and Its Remnants in Germanic Law and Life) (Breslau, 1883), 93; Frederick Pollock and Frederic William Maitland, The History of English Law before the Time of Edward I, 2nd edn, 2 vols. (London, 1898; first published 1895), 1: 364.

${ }^{65}$ Ephraim Neufeld, Ancient Hebrew Marriage Laws: With Special References to General Semitic Laws and Customs (London, 1944), 65 n. 2, 82 n. 2.
} 
the incest taboo, once McLennan derived it from the command of capture. Claude Lévi-Strauss criticized this derivation, ${ }^{66}$ while Edvard Westermarck (1862-1939) regarded rakshasa as the, though legal, wartime exception rather than the norm of primitive marriage. $^{67}$

The anthropological assumption of a universal pattern of primitive "marriage by capture" coincided with the quest for original Indo-Aryan law, thought to be better preserved in the most ancient Indian than in the later Roman and Greek sources. Rakshasa's generalization in turn served to reframe the legal source itself, the Laws of Manu, into which the primitive "marriage by capture" was reinscribed. Thus one reads in Mayne's Treatise on Hindu Law, "The Rakhshasa form is simply the marriage by capture, whose existence, coupled with the practice of exogamy, Mr. McLennan has tracked out in the remotest ages and regions." ${ }^{\prime 68}$ The reference was to the pioneering theorist of rakshasa marriage, the Scottish anthropologist McLennan, who fantasized in 1866, "Race after race has told the same tale. 'With us there was at first no marriage but the Racshasa [sic]. There was neither wooing, nor love, nor pity; and the wife knew not even to bow her head as she followed her lord over the dead bodies of her kinsmen." ${ }^{\prime 69}$ More benevolent forms-consensual elopements and purely ritualized abductions as part of wedding ceremonies-succeeded it, but crucially, for McLennan, rakshasa marriage was the opposite of "caste." The man who enshrined himself in the foundations of social anthropology by coining the opposite marriage patterns of endogamy and exogamy revealed in a footnote in Primitive Marriage (1865) that he had initially considered naming the principle of intra-group marriage "caste." Only the term's baggage of confusing connotations had made him opt for "endogamy" instead. ${ }^{70}$ The "caste principle" of marriage was based on paternal consent, as was possible only among fellow group members. ${ }^{71}$ Its opposite was "exogamy" or rakshasa marriage, the capture of wives from enemy tribes with whom there was and could be no consensual, patriarchal marriage exchange.

On 1 August 1887, a large number of concerned upper-caste/-class Hindu men had assembled in a crowded Calcutta palace hall. Speeches were made, cheered and discussed. The topic of debate was child marriage and the threat to paternal authority represented by attempts at that time to legalize gandharva, or "love marriage." 72 Only the last speaker, a Dr R. Mitra, criticized the conservatism of the prior speakers that entrusted girls to fathers' authority, as both ahistorical and "contrary to 'the

\footnotetext{
${ }^{66}$ Claude Lévi-Strauss, Les structures élémentaires de la parenté (Paris, 1949), 23.

${ }^{67}$ Edward Westermarck, A Short History of Marriage (London, 1926), 112-14.

${ }^{68}$ Mayne, A Treatise on Hindu Law, 66.

${ }^{69}$ John Ferguson McLennan, "Bride-Catching," The Argosy: A Magazine of Tales, Travels, Essays, and Poems 2/7 (1866), 31-42, at 42.

${ }^{70}$ John Ferguson McLennan, Primitive Marriage: An Inquiry into the Origin of the Form of Capture in Marriage Ceremonies (Edinburgh, 1865), $48 \mathrm{n}$.

${ }^{71}$ Ibid., 48.

${ }^{72}$ The Speeches of Eminent Indian Gentlemen on "Hindu Marriage Customs:" Delivered at the Meeting Held on the $6 t$ [sic] August, 1887, at Sobhabazar Rajbati, Calcutta, Convened by Kumar Neel Krishna and Kumar Binaya Krishna (Calcutta, 1887), 83. For a discussion of legal consent in a minor girl's marriage see Hari Singh Gour, Law Relating to Wrongful Restraint, Wrongful Confinement: Along with Criminal Force, Assault, Kidnapping, Rape and Unnatural Offences, revised edn (Allahabad, 1974; first published 1973), 157.
} 
supreme law of nature'."73 He reasoned: "It may shock your sensibility to be told so, but forcible abduction was the usual form of marriage among your remote ancestors [the Aryans], and old Manu, while denouncing it as bestial, was obliged to admit when he wrote that it was a form of marriage and not rape."74

Rakshasa marriage, for this almost certain reader of McLennan and Spencer, was associated with "exogamy" that did not originally carry the stain of miscegenation. $^{75}$ Brahmanical caste endogamy was not the earliest dispensation. ${ }^{76}$ Rakshasa marriage was for this reason often associated with India's "cannibal Dravidian aboriginal inhabitants," whose primitive marriage rite in this way still peeked through the more civilized Aryan ones that supplanted it. ${ }^{77}$ Alternatively, it was associated with the Aryans themselves, in this case naming the custom that had enabled their biological colonization of the subcontinent. ${ }^{78}$ The Census commissioner for Madras Presidency in 1871 even went so far as to blame the Aryan Kshatriyas' custom of rakshasa marriage for the irresponsible amount of interbreeding with the Dravidians that had led to their own downfall and the extraordinary victory of the priestly over the warrior caste, in this variant of the trope of the Aryan degeneration in India. ${ }^{79}$

It is this powerful trope of martial exogamy breaking through brahmanical restraint that should serve to qualify framings of rapes and abductions in communal riots, including in the Indian Partition, as attacks on the (caste) purity of the enemy community, for they ultimately assume a brahmanized, patriarchal speaking position. ${ }^{80}$ In this literature, rapes that are an integral instrument of communal violence are framed through the register of "retaliation" against the real or presumed violation of one's "own" women by the enemy community. ${ }^{81}$ This is misleading in so far as retaliation implies, first, that rapes and abductions are always secondary reactions to perceived prior actions. Second, it implies a measure of reciprocity, if a particularly perverse one. Yet what the act of rakshasa did by definition was to spurn permission and patriarchal consent (both the father's and the community's) that is the basis of patriarchal reciprocity. Rakshasa marriage was a nonreciprocal, unilateral act of force, which at least potentially announced a claim to sovereignty. If more rapes and abductions were the stakes in a war for dominion, this did not actuate a logic of exchange. For reciprocal exchange defines brahma marriage, the first and most meritorious form of marriage according to Manu. This is the father's gift of a girl, decked and adorned, to a husband of his choice. More literally still, exchange defines the only other type of marriage that, though

\footnotetext{
${ }^{73}$ Speeches of Eminent Indian Gentlemen, 86.

${ }^{74}$ Ibid., 87.

${ }^{75}$ Ibid. 87.

${ }^{76}$ H. Bower, Prize Essay: An Essay on Hindu Caste (Calcutta, 1851), 3.

${ }^{77}$ Chintaman Vinayak Vaidya, The Riddle of the Ramayana (Bombay and London, 1906), 149.

${ }^{78}$ Gour, The Hindu Code, iii; Speeches of Eminent Indian Gentlemen, 87-8.

${ }^{79}$ W. R. Cornish, Report on the Census of the Madras Presidency, 1871: With Appendix Containing the Results of the Census in Standard Forms Prescribed by the Government of India (Madras, 1874), 124-5.

${ }^{80}$ See Veena Das, Critical Events: An Anthropological Perspective on Contemporary India (Delhi, 1995), 58-70, 80-81; see also the literature cited in note 27 above.

${ }^{81}$ See, paradigmatically, Ritu Menon and Kamla Bhasin, Borders and Boundaries: Women in India's Partition (New Brunswick, NJ, 1998), 41; Sarkar, "Semiotics of Terror," 2875-6.
} 
condemned, Anglo-Hindu law did not consider "obsolete" in modern times, namely the asura or sale of a bride. ${ }^{82}$ (In its modern transcription, brahma marriage implies dowry, asura marriage the giving of bridewealth.) From both the classics of social anthropology and the feminist critique of marriage, we know that the gift of a girl establishes kinship, political community, and patriarchy. ${ }^{83}$ The reciprocal gifting or selling of brides defines the boundaries of the group(s) within which marriage and thus friendship are possible: in India, caste and religion. ${ }^{84}$ Only the Kshatriya, the quintessential warrior, could rebel against this patriarchal order.

Rakshasa marriage, absorbed into global legal, sociological, and political theorizing from modern Indian thought, presented the potentiality of a violently enacted, gendered social contract. The Kshatriya's sovereign act of bride capture challenges and violently overthrows patriarchy as commonly understood, namely as the father's (or community's) "dominion" over the daughter, which he transfers to the husband, as the inescapable Mayne himself noted. ${ }^{85}$ Paradoxically, then, rakshasa marriage, which marks an extreme of violence against women, in fact topples the existing patriarchal order. With patriarchs unseated, patriarchalism, the theory of the state in which fathers scale up to the sovereign, disintegrates. Disorder directly follows the moment of capture, before a new order has time to emerge. Any new order would likely also be patriarchal, but crucially it would cohere under a different (set of) patriarch(s). Whereas the lens of women's subordination has warranted second-wave radical feminists' metonymical treatment of women "given in marriage" and those "taken in battle," ${ }^{86}$ with ownership and rape constituting their alleged commonality, ${ }^{87}$ the lens of rakshasa reveals these types of marriage as radically distinct, even opposed, events. Rakshasa marriage in fact voided patria potestas (over children, slaves, and wife $^{88}$ ) as originated only in a much later stage of human social evolution, though Golapchandra Sarkar Sastri (1846-1915), a vakil at Calcutta's High Court and a prominent legal thinker who gave the prestigious Tagore Law Lecture in 1888, anticipated their feminist identification. ${ }^{89}$ The trope of rakshasa marriage thus cuts against the nineteenth-century emergence of increasingly monetized and marketized forms of arranged marriage in India. ${ }^{90}$ It militates against the Indian iteration, if one so wills, of what Carole Pateman has famously

\footnotetext{
${ }^{82}$ Mayne, A Treatise on Hindu Law, 69. The asura marriage by purchase is not to be confused with the (rare) ritual selling of wives as a means of working-class divorce in eighteenth- and nineteenth-century Britain. See E. P. Thompson's classic essay, "The Sale of Wives," in Thompson, Customs in Common (London, 1993), 400-66.

${ }^{83}$ See Lévi-Strauss, Structures élémentaires, 52-86; Gayle Rubin, "The Traffic in Women: Notes on the 'Political Economy' of Sex," in Rayna R. Reiter, ed., Toward an Anthropology of Women (New York and London, 1975), 157-210, at 171-83, 204-10; Das, "Sexual Violence," 2416.

${ }^{84}$ See, for example, Uma Chakravarti, Gendering Caste: Through a Feminist Lens (Calcutta, 2003), 30-32.

${ }^{85}$ Mayne, A Treatise on Hindu Law, 67.

${ }^{86}$ Rubin, "Traffic in Women," 175.

${ }^{87}$ See Andrea Dworkin, Pornography: Men Possessing Women (New York, 1981), 19.

${ }^{88}$ The subjection of all wives under the husband's patria potestas was not operative in Roman times but only dates to the Renaissance. Becker, Gendering the Renaissance, 195-9.

${ }^{89}$ Golapchandra Sarkar Sastri, A Treatise on Hindu Law, 4th, revised and enlarged edn (Calcutta, 1910), 86.

${ }^{90}$ See Rochona Majumdar, Marriage and Modernity: Family Values in Colonial Bengal (Durham, 2009).
} 
dubbed the "sexual contract." For, in rakshasa marriage, the warrior deposes the father as king.

\section{Krishna and Ravana}

Kshatriyas are the designated kings ( $r a j a)$ of Sanskrit political theory, ${ }^{91}$ historically prompting de facto kings to seek admission into Kshatriya caste (varna) status. ${ }^{92}$ Associated with ancient kshatriyahood, rakshasa marriage gestured towards courtly practice in precolonial north India, where females acquired as captures as well as gifts and purchases were absorbed into the polygamous royal zenana, whose size reflected the grandeur of the kingdom. ${ }^{93}$ The association between wife capture and warrior aristocracy was a strong and abiding colonial trope. It was duly observed among the Rajputs, India's most successful claimants to Kshatriya status in the present age, to the point where "Rajput" even came to appropriate the meaning and assimilative function of "Kshatriya." Extensive marriage networks and a continuous state of war buttressed the power of the Rajput clans who had risen to power in medieval Rajasthan. ${ }^{95}$ In the monumental Annals and Antiquities of Rajast'han (1829-32) that did so much to mystify them, colonial officer and historian James Tod (1782-1835) wondered at the Rajputs' failure to advance beyond the rude laws of war that allowed victors to carry off and forcibly marry their opponents' women, which "both Moses and Menu [sic]" sanctioned and only Christianity and medieval chivalry eradicated. ${ }^{96}$ Under the circumstances, the Rajputs developed a unique method of preserving their honor even in defeat. This was the women's self-immolation, johur. ${ }^{97}$ In the Punjabi context, in 1911, Census commissioners explained traditional wedding processions that staged the mock assault of the mounted and sword-wielding bridegroom's party on the bride's defenders as a popular emulation of royal wedding rites. These were in turn "remnants of the marriage by capture (Rákshasa)" that would have once been "largely prevalent amongst the warrior classes." 98

\footnotetext{
${ }^{91}$ Even in ancient times kingship was only preferably, never exclusively, in Kshatriya hands. See Romila Thapar, A History of India, vol. 1 (Harmondsworth, 1966), 54.

${ }^{92}$ Romila Thapar, "The Image of the Barbarian in Early India," Comparative Studies in Society and History 13/4 (1971), 408-36, at 428-9; Brajadulal Chattopadhyaya, The Making of Early Medieval India (Delhi, 1994), 59.

${ }^{93}$ See Indrani Chatterjee, "Gossip, Taboo, and Writing Family History," in Chatterjee, Unfamiliar Relations, 222-60, at 229; Daud Ali, "Courtly Love and the Aristocratic Household in Early Medieval India," in Francesca Orsini, ed., Love in South Asia: A Cultural History (Cambridge, 2006), 43-60, at 50; Ramya Sreenivasan, "Drudges, Dancing Girls, Concubines: Female Slaves in Rajput Polity, 1500-1850," in Chatterjee and Eaton, Slavery and South Asian History, 136-61, esp. 137; Priyanka Khanna, "Service, Sex and Sentiments: Concubinage in the Early Modern Rajput Household of Marwar," in Nitin Sinha, Nitin Varma, and Pankaj Jha, eds., Servants' Pasts, 2 vols. (Hyderabad, 2019), 1: 197-226, at 200, 202.

${ }^{94}$ See Chattopadhyaya, The Making of Early Medieval India, 59, 63-4, 8-2; see also Norbert Peabody, Hindu Kingship and Polity in Precolonial India (Cambridge, 2003), 37-8.

${ }^{95}$ See Peabody, Hindu Kingship and Polity, 37-8, 118; Chattopadhyaya, The Making of Early Medieval India, 77-9, 86-7.

${ }^{96}$ James Tod, Annals and Antiquities of Rajast'han, or the Central and Western Rajpoot States of India, 2 vols. (London, 1829), 1: 640.

${ }^{97}$ Ibid., 641.

${ }^{98}$ Pandit Harikishan Kaul, Census of India 1911, vol. 14, Punjab, part 1, Report (Lahore, 1912), 275.
} 
The problem was that medieval Brahmin orthodoxy had declared the Kshatriya varna to be extinct in the present Kali Yuga, or Dark Age. Tussles inevitably ensued between rulers and the Brahmins who alone could recognize them as Kshatriyas and consecrate them as Hindu kings. ${ }^{99}$ In 1876, a British judge presiding over an inheritance dispute at Bombay's High Court played on the trope of the extinct Kshatriyas in a curious way. In his judgment, Mr Justice Green remarked that had the ancient Kshatriyas really been obligated to obtain a "lawful wife" exclusively in the rakshasa manner, this "would of itself account for the supposed extinction of this class." ${ }^{100}$ The judgment established the brahmanical norm of brahma marriage (the gift of a girl, or kanyadan) for all Hindus. ${ }^{101}$ Specific caste "custom" would no longer be recognized. ${ }^{102}$ Green justified this by assuming the eventual sanskritization of all social and religious customs towards the brahmanical ideal, in this case towards Manu's preferred brahma marriage. ${ }^{103}$ His reference to rakshasa marriage that imperiled Kshatriya reproduction in this context may not have been altogether serious, but it was influential. The redefinition of rakshasa marriage as "allowable" though "not obligatory" even for the ancient Kshatriyas permitted Indians like the author of The Position of Women in Hindu Law, in 1913, to sanitize the past of Hindu marriage. ${ }^{104}$ At the same time, Green positioned rakshasa marriage exactly in its proper context as I see it, namely as a trope pointing towards kshatriyahood as a lack in modern India, and as the constitutive lack of Hindu nationalism.

Rakshasa marriage signified a violation of both law and dharma (meaning not only "religion" but "morality" or "law") for all modern Hindus, who no longer possessed the prerogatives of the ancient Kshatriyas. Constituted around the lack of true Kshatriyas whose dharma of action could counter Vedantic quietism, Hindu nationalism launched its ideological effort to again transform Hindus into warriors. ${ }^{105}$ This entailed a radical transvaluation of values. It necessitated the elevation of the Kshatriyas' svadharma (their caste-specific dharma) that committed them to

\footnotetext{
${ }^{99}$ Sheldon Pollock, The Ends of Man at the End of Premodernity (Amsterdam, 2004), 69-76; Madhav Deshpande, "Ksatriyas in the Kali Age? Gāgābhatta and His Opponents," Indo-Iranian Journal 53/2 (2010), 95-120; Rosalind O'Hanlon, "Caste and Its Histories in Colonial India: A Reappraisal," in New Directions in Social and Economic History: Essays in Honour of David Washbrook, special issue, Modern Asian Studies 51/2 (2017), 432-61, at 448, 452, 456-7.

${ }^{100}$ Jaikisondas Gopaldas v. Hariksundas Hullochandas and Another (1876) ILR 2 Bom 9, at 14.

${ }^{101}$ Ernest John Trevelyan, Hindu Family Law: As Administered in British India (London, 1908), 51; William Burge, The Comparative Law of Marriage and Divorce (Reprinted from Burge's Commentaries on Colonial and Foreign Laws), ed. Alexander Wood Renton and George Grenville Phillimore (London, 1910), 216.

${ }^{102}$ For the legal marginalization of caste "custom" and reordering of Indian property according to British notions in the last quarter of the nineteenth century see Agnes, Law and Gender Inequality, 47-9; Eleanor Newbigin, The Hindu Family and the Emergence of Modern India: Law, Citizenship and Community (New York, 2013); Prem Chowdhry, "Customs in a Peasant Economy: Women in Colonial Haryana," in Kumkum Sangari and Sudesh Vaid, eds., Recasting Women Essays in Indian Colonial History (New Brunswick, 1990), 302-36; Stephens, Governing Islam, 88-103; Majumdar, Marriage and Modernity, 208-37; Chatterjee, "Gossip, Taboo," 237-8; Sreenivas, Wives, Widows, and Concubines, 28, 30-44.

${ }^{103}$ Gopaldas v. Hullochandas, 14, 9.

${ }^{104}$ Dwarka Nath Mitter, The Position of Women in Hindu Law (Calcutta, 1913), 216.

${ }^{105}$ See also Gupta, Sexuality, Obscenity, Women, 230-39.
} 
violence, over the traditional hegemony of brahmanical svadharma whose virtue was nonviolence (ahimsa). ${ }^{106}$ Emulation of brahmanical patriarchy was the traditional route to social mobility (sanskritization) ${ }^{107}$ But beginning in the late nineteenth century, not only Dalits claimed to be déclassé Kshatriyas. ${ }^{108}$ Hindu nationalism's overwhelmingly Brahmin luminaries, too, adopted a Kshatriya identity. They particularly sought to emulate the Kshatriya mode of usurping patriarchy. For rakshasa's most violent theoretician, the founder of Hindutva, V. D. Savarkar, Partition violence itself staged a war in which the capture of enemy women spelled victory.

In a much-loved story in the epic Ramayana that is as ubiquitous in South and Southeast Asia as is the story of the Nativity of Jesus in the West, Sita, the god-king Rama's wife, was abducted by the demon-king Ravana, who desired her as his wife and carried her away to Sri Lanka. Sita was rescued, but had she remained faithful to Rama during her captivity? As subsequent trials actually prove her purity but fail to convince her doubting spouse and his subjects, the long-suffering heroine begs her mother, Earth, to swallow and remove her from this misery. And so the model of virtuous, ill-treated wifehood, Sita, vanishes in one version of the story. ${ }^{109}$ The recovery of Sita from Ravana's captivity, as Ritu Menon, Kamla Bhasin, and Urvashi Butalia's groundbreaking works on women's experiences of Partition have suggested, became a potent rhetorical foil for the repatriation of abducted Hindu and Sikh women living in Muslim families in Pakistan to newly independent India. ${ }^{110}$ As Veena Das has persuasively argued, the bilateral recovery operation itself ended the state of exception of civil war in 1947, inaugurating law and sovereignty in both countries. ${ }^{111}$ The Indian (and Pakistani) nation-state emerged as a patriarchal order that grounded the social contract in the sexual contract, as violence committed in the state of exception was ended and folded into the new order through the restoration of Sita. ${ }^{112}$

\footnotetext{
${ }^{106}$ See Wendy Doniger and Brian K. Smith, "Introduction" in Doniger and Smith, trans., The Laws of Manu (London, 1991), xv-lxxvii, at xxxix.

${ }^{107}$ See Uma Chakravarti, "Reconceptualising Gender: Phule, Brahmanism and Brahmanical Patriarchy," in Anupama Rao, ed., Gender \& Caste (London, 2005; first published 2003), 164-79, at 169.

${ }^{108}$ Rosalind O'Hanlon, "Maratha History as Polemic: Low Caste Ideology and Political Debate in Late Nineteenth-Century Western India," Modern Asian Studies 17/1 (1983), 1-33; Shruti Kapila, "Ambedkar's Agonism: Sovereign Violence and Pakistan as Peace," Comparative Studies of South Asia, Africa and the Middle East 39/1 (2019), 184-95, at 189-90.

${ }^{109}$ See Attipate Krishnaswami Ramanujan, "The Three Hundred Rāmāyanas: Five Examples and Three Thoughts on Translation," in Paula Richman, ed., Many Rāmāyanas: The Diversity of a Narrative Tradition in South Asia (Berkely, 1991), 22-48, at 39.

${ }^{110}$ Ritu Menon and Kamla Bhasin, "Abducted Women, the State and Questions of Honour: Three Perspectives on the Recovery Operation in Post-Partition India," in Kumari Jayawardena and Malathi de Alwis, eds., Embodied Violence: Communalising Women's Sexuality in South Asia (New Delhi, 1996), 1-31, at 6; Butalia, The Other Side of Silence, 177-8, 189; Urvashi Butalia, "Community, State and Gender: On Women's Agency during Partition,” Economic and Political Weekly 28/17 (1993), WS12-24, at WS18.

${ }^{111}$ Veena Das, Life and Words: Violence and the Descent into the Ordinary (Berkeley, 2007), 21, 34.

${ }^{112}$ See ibid. For popular Hinduism's traditional unease with the abduction of Sita, who is an incarnation of the goddess Lakshmi, see George A. Grierson, "On the Adbhuta-Ramayana," Bulletin of the School of Oriental Studies, University of London 4/1 (1926), 11-27.
} 
The issue with Das's analysis is that it literally upends the story (though I believe it to be correct in its implications for postcolonial sovereignty). Das takes recovery as foundational but not the foregoing abduction of Sita. Yet it was the event of the exception-openness, rather than a closed political order ${ }^{113}$-that captivated the nationalist imagination and founded "the political" in India, as Shruti Kapila has shown. ${ }^{114}$ Kapila argues that violence and power, which Hannah Arendt disaggregates into opposites, ${ }^{115}$ fall into a more intimate arrangement in the Indian case, where fraternal violence of an almost unimaginable scale shaped the making of the postcolonial nation-state. ${ }^{116}$ The state of exception, being war, could indeed be reframed as a descent into the state of nature with seductive, if misleading, ease, as Darwin more than Hobbes haunted the nineteenth- and twentieth-century theorists of rakshasa. ${ }^{117}$ It follows that what the Indian patriarchal state "remarkably quickly" "sutured"118 after 1947 was the chronologically and conceptually prior exception that was rakshasa marriage. Hindu nationalist political thought in the lead-up to civil war rendered rakshasa not only imaginable but indeed lawful during the exception. It is this discourse of force that I am concerned with here, and Krishna was its hero.

Without a doubt the major Hindu nationalist deity before independence, Krishna counsels his friend, the hero Arjuna, to do his duty as a Kshatriya and fight, even kill, his own kin and friends in the central episode related in the epos Mahabharata, the Bhagavad Gita. Its early twentieth-century retelling, as Kapila has shown, founded the Indian political as fraternity and fracticide (between Hindus and Muslims), with a deliberate yet unspecified gesture towards the Indian Partition. ${ }^{119}$ Yet Krishna not only counseled Arjuna to fight in the Kurukshetra War, but also to walk the way of a warrior in amorous matters. Strikingly, both appealed to a Kshatriya's duty (dharma) in the pioneering historicization of Krishna by Bengal's foremost novelist in the nineteenth century, Bankim Chandra Chatterjee (1838-94), titled Krishnacharitra or "Character of Krishna," and published between 1886 and $1892 .{ }^{121}$ Meriting Bankim's reputation as a Hindu revivalist and (proto-)Hindu nationalist, Krishnacharitra endeavored to counter the

\footnotetext{
${ }^{113}$ Shruti Kapila and Faisal Devji, "Introduction," in Kapila and Devji, eds., Political Thought in Action (Cambridge, 2013), ix-xv.

${ }^{114}$ Kapila, "History of Violence," 179, 195.

${ }^{115}$ Hannah Arendt, On Violence (Orlando, 1970; first published 1969), 56; Arendt, The Human Condition (Chicago, 1958), 199-204.

${ }^{116}$ Kapila, "History of Violence,"178-9.

${ }^{117}$ Spencer, The Principles of Sociology, 1: 649-64; Gour, The Hindu Code, iii; Maine, Dissertations on Early Law, 206-7, 214-15.

${ }^{118}$ Kapila, "History of Violence," 180.

${ }^{119}$ Ibid., 180, 182.

${ }^{120}$ Bankim Chandra Chatterjee, Krishna-Charitra, trans. Pradip Bhattacharya (Calcutta, 1991; first published 1886). My gratitude to Julius J. Lipner for advice on the choice of translation, and to Salmoli Choudhuri for comparing all translated quotes to the Bengali original. Where they differ, I cleave to Choudhuri's rather than Bhattacharya's translation.

${ }^{121}$ For Bankim's transformation of Krishna into a historical figure see Sisir Kumar Das, The Artist in Chains: The Life of Bankimchandra Chatterji (New Delhi, 1984), 163-4, 173; Sudipta Kaviraj, The Unhappy Consciousness: Bankimchandra Chattopadhyay and the Formation of Nationalist Discourse in India (Oxford, 1995), 79-83.
} 
Hindus' historical deficiency of action and militarism that had made them prey to Muslim and British rule, by forging them into agents in the image of Krishna. ${ }^{122}$ To this aim, Bankim insisted that again acting on Krishna's counsel, Arjuna had gained Subhadra as his wife without her love, invitation, or consent, by rakshasa marriage based on foregoing harana (Sanskrit: "capture," "theft").

Before showering moral judgment on the harana of Subhadra, Bankim requests his reader to "kindly forget whatever he might have read" of this episode in popular literature or "heard from the rhapsode of his grandmother." 123 In popular tradition, Subhadra falls head over heels in love with Arjuna at the mere sight of him. ${ }^{124}$ It follows that Subhadra's abduction is staged and the marriage by capture in reality a case of the girl's own choice of a husband, or swayamvara (usually by a staged contest), corresponding to the gandharva form of wedding. Yet Bankim insists that Subhadra's was not a case of a lady engineering her own abduction by her lover. For, instead of Subhadra, it was Arjuna who was "bewitched" by Subhadra, whom he has glimpsed without her notice. ${ }^{125}$ It is none other than Krishna, Arjuna's confidant, who dismisses the option of swayamvara as unreliable for Arjuna's purposes, as no one could predict the girl's heart and choice. A nod to the Dharmashastra subsequently reveals the only other "praiseworthy" course of action for a Kshatriya like Arjuna to be abduction by rakshasa marriage. Unlike Justice Green, Bankim not only regarded rakshasa and gandharva marriage alone as appropriate for Kshatriyas, but insisted that rakshasa was to be preferred, as gandharva's motivation by sexual desire would have offended Krishna's and Arjuna's supreme moral sensibility. It followed for Bankim that rakshasa marriage was truly the only marriage rite befitting the ancient Kshatriyas. ${ }^{126}$

To further complicate matters, Subhadra, whose abduction he unscrupulously plotted, is Krishna's own sister. Not only that, but Krishna himself married by capture. Thus, Bankim informs us, Krishna won his chief consort Rukmini, Arjuna won Subhadra, and the celibate hero Bhishma won three princesses of Kashi for his brother, by harana and subsequent rakshasa wedding. This did not mean that they had committed an "outrage" (atyachar). ${ }^{127}$ In Krishna and Rukmini's case, there was mutual attraction. The same unsparing textual criticism that stripped Krishna of some 16,000 wives even allowed Bankim to consider the story of Rukmini's abduction and Krishna's subsequent battle with her brother Rukmi, if not the conflict surrounding the marriage, as a later insertion into the original Mahabharata. ${ }^{128}$ But Subhadra's harana not only belonged in the original

\footnotetext{
${ }^{122}$ See Uma Chakravarti, "Whatever Happened to the Vedic Dasi? Orientalism, Nationalism and a Script for the Past," in Kumkum Sangari and Sudesh Vaid, eds., Recasting Women: Essays in Colonial History (New Delhi, 1989), 27-87, at 49; Tanika Sarkar, "Imagining Hindurashtra: The Hindu and the Muslim in Bankim Chandra's Writings," in David Ludden, ed., Contesting the Nation: Religion, Community, and the Politics of Democracy in India (Philadelphia, 1996), 162-84, at 164-5, 168-9; Andrew Sartori, Bengal in Global Concept History: Culturalism in the Age of Capital (Chicago, 2008), 108.

${ }^{123}$ Chatterjee, Krishna-Charitra, 197.

${ }^{124}$ Ibid., 197.

${ }^{125}$ Ibid., 197.

${ }^{126}$ Ibid., 197-8, 201.

${ }^{127}$ Ibid., 163.

${ }^{128}$ Ibid., 166, 180.
} 
epic but was essential to it, even more so than Draupadi's famous swayamvara, as it was Subhadra's and not Draupadi's descendants that became the line of kings. ${ }^{129}$ Now, Subhadra's feelings for Arjuna were entirely unknown and unconsulted. ${ }^{130}$

The obvious resemblance of the epic haranas and rakshasa marriages to the modern legal offenses of "abduction" and "kidnapping" produced problems for nineteenth-century Hindu elites that were best solved by reference to their "romance" and legality at the time. ${ }^{131}$ Abductions perpetrated by gods and heroes are deeply ingrained in the Hindu tradition, though discomfort with Krishna's history of abduction may be as old as the ninth-century Bhagavata Purana. ${ }^{132}$ While the older Vishnu Purana still left no doubt that it was in the rakshasa manner that Lord Krishna wed his beloved Rukmini before following this up with due Vedic ceremonial, subsequent scriptures tended to embellish the latter ritual and drop the uncouth signifier rakshasa. ${ }^{133}$ The nineteenth and twentieth centuries adopted legalism and romance as strategies of whitewashing. A famous twentieth-century exponent of this tendency is the great Sanskrit scholar, advocate, and authority on ancient Hindu law to this day, Pandurang Vaman Kane (1880-1972). Kane's History of Dharmaśastra, published in five volumes between the 1930s and the 1960s, cites Arjuna and Subhadra's case as a famous example of the gandharva form of marriage "that was very much in vogue among royal families." Its "mixture" with rakshasa marriage was sanctioned in cases where the girl loves the boy, who can only obtain her by fighting her disapproving parents. ${ }^{134}$ Senior legal authorities like Jagannanth Raghunath Gharpure in 1939, let alone popular Hinduism, agreed with Kane's position on Subhadra's love for Arjuna. ${ }^{135}$ The notable archeaologist and historian of ancient India at Banaras Hindu University, Anant Sadashiv Altekar, offered a third way in his 1938 book The Position of Women in Hindu Civilisation, cited in the Hindu Code debates in $1945 .{ }^{136}$ Though agreeing that Subhadra loved Arjuna, Altekar unambiguously classified their marriage along with Krishna and Rukmini's as a "Rākshasa," "Kshātra," or "Kshatriya marriage." 137 "[W]arrior mentality" at the time of the Mahabharata, he explained, had rejected the brahma and asura forms of marriage as dishonorable. But rakshasa marriage had subsequently fallen into disrepute even among the Kshatriyas. ${ }^{138}$

\footnotetext{
${ }^{129}$ Ibid., $195-6$.

${ }^{130}$ Ibid., 199.

${ }^{131}$ Bulloram Mullick, Krishna and Krishnaism (Calcutta, 1898), 40-41.

${ }^{132}$ See Heidi Pauwels, "Stealing a Willing Bride: Women's Agency in the Myth of Rukmi'inīs Elopement," Journal of the Royal Asiatic Society 17/4 (2007), 407-41, at 415.

${ }^{133}$ See Akon Chandra Saikia, "The Rukmini Harana Legend in Sanskrit and Later Indian Literature" (Ph.D. thesis, Gauhati University, Guwahati, 1988), 60, 80, 87, 92-4.

${ }^{134}$ Kane, History of Dharmaśāstra, 2: part 1, 522-3.

${ }^{135}$ J. R. Gharpure, Rights of Women under the Hindu Law, Sir Lallubhai A. Shah Lectures, 1939 (Bombay, 1943), 26.

${ }^{136}$ Divan Bahadur V. V. Joshi, in Written Statements Submitted to the Hindu Law Committee 1945, 2 vols. (Madras, 1947), IOR/V/26/100/17, British Library, London, 1: 10.

${ }^{137}$ Anant Sadashiv Altekar, The Position of Women in Hindu Civilisation: From Prehistoric Times to the Present Day (Benares, 1938), 44-5.

${ }^{138}$ Ibid.
} 
If Bankim, who had domesticated the historical romance in Bengali, ${ }^{139}$ barred the escape route of romance in Krishnacharitra, he deliberately turned against his contemporaries' moral sensibilities, explicitly including his own. Why? Because Bankim aimed a blow at the Westernized "reformer." A reformer, wrote Bankim, might believe himself to be the "the ideal man," and if Krishna was an ideal man, "then he ought to have been a reformer," who took action against rakshasa marriage. ${ }^{140}$ Bankim had himself been something of a reformer of women's rights, but recanted as he converted to Hindu revivalism in the $1880 \mathrm{~s}$. ${ }^{141}$ Written after this hiatus, Bankim's agenda in Krishnacharitra was still not to base gender relations on rakshasa marriage. ${ }^{142}$ Instead, it was to free Krishna from centuries of effeminizing distortions that had made him the butter-stealing child or great lover of cowherdesses (gopis) of Bengali folk devotionalism. ${ }^{143}$ Replacing this sentimental picture with one of Krishna's warrior mentality and morality as an ideal for modern Hindu men required Bankim to transcend brahmanical patriarchy. As Bankim made explicit, this required his readers to drop the standard of nineteenth-century morality that would condemn, and the law that would prosecute, Krishna. ${ }^{144}$ The only standard that readers should apply was the eternal, universal law of dharma, which would exonerate Krishna and the entire affair of the Subhadra-harana. It was Krishna's dharma to give Subhadra to the worthiest suitor, Arjuna, as it was Arjuna's to obtain his wife in the way of a warrior. Force was justified in this case where it ensured compliance with Kshatriya dharma and universal welfare. $^{145}$ In demonstrating the historical growth of supposedly eternal Hindu mores, Bankim revealed the sheer dynamism and power of the Kshatriyas of yore. As a Kshatriya, Arjuna, though preemptively asking his own kin for consent, ${ }^{146}$ was not bound by reciprocal patriarchy. It is this shared Kshatriya ethos that, for Bankim, ultimately convinces Subhadra's and Krishna's clan, the Yadavas, to abandon their desire for waging war on Arjuna. Again, it is Krishna who advises them that Arjuna has not dishonored their clan. He has not insulted them by paying bride price, nor has he injured his own honor by begging the girl's hand from her parents. In abducting Subhadra, he has instead acted as a true Kshatriya, thereby conferring prestige on his chosen bride and in-laws. ${ }^{147}$ If channelled through the Kshatriya idiom, self-willing power rather than paternal consent lent itself to the social contract. This social contract was explicitly gendered, and (at least potentially) violently rather than consensually founded.

What are we to make of this situation in which Krishna, beloved god and hero of the Mahabharata, endorses the same practice that is condemned as that of Ravana,

\footnotetext{
${ }^{139}$ See Das, The Artist in Chains, 27-8.

${ }^{140}$ Chatterjee, Krishna-Charitra, 203.

${ }^{141}$ Sarkar, "Imagining Hindurashtra," 164-5, 168-9; Sartori, Bengal in Global Concept History, 108.

${ }^{142}$ Chatterjee, Krishna-Charitra, 203.

${ }^{143}$ Ibid., 21; see Kaviraj, Unhappy Consciousness, 77-8, 90-93, 95-101; Sarkar, "Imagining Hindurashtra," 170; Sartori, Bengal in Global Concept History, 123.

${ }^{144}$ Chatterjee, Krishna-Charitra, 194.

${ }^{145}$ Ibid., 198-200. Contrast my reading with Sarkar, Hindu Wife, 174, who suspects Bankim's ultimate discomfort with his justification of force.

${ }^{146}$ Chatterjee, Krishna-Charitra, 198.

${ }^{147}$ Ibid., 202.
} 
the enemy in the Ramayana? Bride capture often appeared as that which the "other" did: the Dravidian, in an article of 1921 in the weekly Young India edited by the theorist of nonviolence, Gandhi himself ${ }^{148}$-the primitive, the enemy, the Rakshasa. It followed that the homonymy between rakshasa marriage and the Rakshasas with a capital $\mathrm{R}$ could be no coincidence. For Kane, the wedding "[wa]s called rāksasa because rāksasas (demons) are known from legends to have been addicted to cruel and forceful methods." ${ }^{149}$ Rakshasa marriage indexed the prevalent form of marriage among the Rakshasas, for Chintaman Vinayak Vaidya - an influential Marathi historian, ${ }^{150}$ a Tilakite, and former chief justice of the princely state of Gwalior-in a book titled The Riddle of the Ramayana (1905) and dedicated to the Maharaja of Baroda, ${ }^{151}$ as it did for McLennan in Primitive Marriage, written almost half a century earlier. ${ }^{152}$ Identifying rakshasa marriage with Ravana's tribe in ever tighter intertextuality, a 1909 translation of the Ramayana of Valmiki even hosted a discussion of Manu's eight forms of marriage and the (im)propriety of rakshasa marriage in its extensive commentary. ${ }^{153}$ Yet intriguingly, for Vaidya, the fact that Sita's abduction followed the Rakshasas' customary form of marriage only served to prove her chastity, as it would have also been these demons' "custom" to delay intercourse for one year to allow the wife abducted from her living husband to "reconcile herself to her situation." 154

No such allowances were made where the aim of vanquishing one's enemy came to require nothing short of a full identification with Ravana, the villain of Hindu tradition. None other than the arch-Hindu nationalist "Veer" Savarkar drew this requirement to its logical conclusion when he deliberately appropriated the ways of Ravana, who had become synonymous with the figure of the sexually rapacious Muslim. ${ }^{155}$ A Maharashtrian Brahmin drawn early in life to the violent revolutionary brand of Indian nationalism, which earned him fourteen years in prison, Savarkar coined the ideological core of Hindu nationalism in his 1923 treatise Essentials of Hindutva. ${ }^{156}$ Later as leader of the Hindu nationalist party, the All India Hindu Mahasabha, and implicated in the murder of Mahatma Gandhi in 1948, Savarkar spent his life fanning the flames of violence like no other. With devastating consequence and consistency, Savarkar's Hindutva that is entirely couched in the exception of war commanded Hindus to become Kshatriyas by quite literally becoming rakshasa-practicing Muslim "Rakshasas." Savarkar's project of Hindu

\footnotetext{
${ }^{148}$ Principal Dhruva, "Canons of Interpretation," in Mohandas Karamchand Gandhi, ed., Young India: 1919-1931 in Thirteen Volumes, 14 vols. (Ahmedabad, 1981), 3: 362-3, at 363.

${ }^{149}$ Kane, History of Dharmaśāstra, 2: part 1, 519.

150"Report of the Age," IOR/L/PJ/6/1797, 112.

${ }^{151}$ Vaidya, Riddle of the Ramayana, 158-50.

${ }^{152}$ McLennan, Primitive Marriage, Appendix, 310.

${ }^{153}$ C. R. Sreenivasa Ayyangar, The Ramayana of Valmeeki: Rendered into English with Exhaustive Notes by C. R. Sreenivasa Ayyangar (Madras, 1910), 464, 474-5.

${ }^{154}$ Vaidya, Riddle of the Ramayana, 174.

${ }^{155}$ I discuss Savarkar in detail in Luna Sabastian, "Indian Political Thought and Germany's Fascism, 1918-1950" (unpublished Ph.D. thesis, University of Cambridge, Cambridge, 2020), 87-139.

${ }^{156}$ Savarkar [A. Maratha, pseud.], Essentials of Hindutva (Nagpur, 1923).
} 
dominion emulated India's so-called conquerors, as even before the Muslims, the British had been accused of raping the Indian motherland and its women rakshasa-style. ${ }^{157}$ To inspire such transformation, Savarkar deliberately strewed rumors of Muslims abducting, seducing, forcibly converting, and marrying Hindu women, all with the aim of increasing their numbers and overpowering Hindus. ${ }^{158}$ In 1925, Savarkar dropped one such rumor on the crucial locale of Kohat, where communal violence had just forced the first mass evacuation of one community, the Hindus. ${ }^{159}$ In an article titled "The 'Suffering' Muslims of Kohat" published in the newspaper Mahratta on 1 March 1925, Savarkar claimed nothing less than that the Quran permitted sex with an enslaved female. ${ }^{160}$ He was joined in this view by the founder of the Jamaat-e-Islami and one of the major theorists of Islamism, Sayyid Abul A'la Maududi (1903-79). ${ }^{161}$ Crucially, Savarkar drew an explicit connection between war and the capture of female slaves. The Quran, he insisted, allowed "capturing [a woman] as an article of the booties of war." ${ }^{162}$ If Muslims had religious sanction to fill their harems with Hindu mistresses captured in their war with Hindus, then the war strategy that presented itself to Savarkar was for Hindu males to practice like for like. Savarkar's grotesque identification with his enemy thus overtly made Muslim women's bodies the battleground and booty that they-as women of all "communities"-indeed became during the Indian Partition. ${ }^{163}$ The specificity of Hindutva's social contract in the crucial decades leading up to Partition was its rejection of brahmanical patriarchy and ideologies of purity. Weaponizing rakshasa marriage, Savarkar's Hindutva sought to gain victory and sovereignty through the violent dispossession of Muslim patriarchs and appropriation of Muslim women.

Hindutva spearheaded the framing of a Hindu woman's conversion and marriage to a Muslim, as all conversions to Islam, as forced and fraudulent by definition. This was in keeping with a long Anglo-Indian legal tradition that embedded women in the patriarchal family, producing, amongst other things, a confusing proliferation of legal ages of maturity for girls. ${ }^{164}$ Infringement against patriarchy was framed as "abduction," "kidnapping," "seduction," or "enticement" away from the "lawful guardianship" of a father or husband, to whom, like property, it warranted restitution: from nineteenth-century Indian women's escapes from domestic tyranny and work migration, ${ }^{165}$ with notable similarity of rhetoric and

\footnotetext{
${ }^{157}$ Bengali Translator's Office, "Report on Native Papers for the Week Ending the 3rd March 1891," South Asia Open Archives (SAOA), 170.

${ }^{158}$ For the demographic threat in the Hindu nationalist imaginary see Pradip Kumar Datta, "Dying Hindus': Production of Hindu Communal Sense in Early 20th Century Bengal," Economic and Political Weekly 28/25 (1993), 1305-19.

${ }^{159}$ See Neeti Nair, Changing Homelands: Hindu Politics and the Partition of India (Cambridge, MA, 2011), 60 .

${ }^{160}$ Savarkar, "The 'Suffering' Muslims of Kohat," The Mahratta, 1 March 1925, 110.

${ }^{161}$ William Gervase Clarence-Smith, Islam and the Abolition of Slavery (Oxford, 2006), 188.

${ }^{162}$ Savarkar, "Suffering' Muslims," 110.

${ }^{163}$ Sabastian, "Indian Political Thought, 161-3.

${ }^{164}$ For some of the inconsistencies in defining girlhood and womanhood in India see Ashwini Tambe, Defining Girlhood in India: A Transnational History of Sexual Maturity Laws (Champaign, IL, 2019), esp. Ch. 3.

${ }^{165}$ See Sen, "Offences against Marriage," 100; Stephens, Governing Islam, 60-64, 101-3.
} 
phraseology to the restoration of women abducted during the Indian Partition-a point that has remarkably gone unnoticed. Force affecting consent rendered "sacramental" Hindu marriages "voidable" even in early drafts of the controversial Hindu Code Bill. ${ }^{166}$ In the wake of Partition, it was the assumption of force in "abducted" women's marriages and conversions that allowed India and Pakistan's recovery operations to declare them void and repatriate (or reabduct) the women. ${ }^{167}$

Signposting women's removal from family control, references to rakshasa marriage dotted the controversy over the reform of Hindu personal law that jolted through legislatives from the 1920s onwards and on to the final passage of the Hindu Code Bill only after independence, in 1955-6. Ventures into India's past and epic traditions allowed reformers within the Legislative Assembly to undermine the conservative defenders of marriage "tradition." The Mahabharata in particular could be construed as a time before the "evolution" of the same sacramental marriage that Hindu conservatives posited as eternal and defended from reformist meddling on this basis: ${ }^{168}$ ancient India had historically known rakshasa marriage, polygamy, and divorce. Foremost among the reformers was Hari Singh Gour (1870-1949), a distinguished legal mind and, from 1921 onwards, an untiring social reformer within the Legislative Assembly, which he pushed to consider civil marriage and raise the age of consent (in India meaning the consummation of marriage) for girls. ${ }^{169}$ Gour's important summary treatment of The Hindu Code of 1919 framed the Laws of Manu as an archive of objectionable practices of a bygone age unjustifiably elevated into "unchangeable" legal authority. Having denounced ancient Hindu society's Brahmin supremacism and rampant female infanticide, he turned to the definition of rakshasa marriage as to a triumphant conclusion: "After this who would doubt the legality of the rape of the Sabine women?"170 In other words: after this, who could accept the lawgiver who legalized rakshasa marriage?

On 18 September 1951, Narhar Vishnu Gadgil (1896-1966), a veteran freedom fighter and social reformer, urged the Constituent Assembly that acted as interim parliament to pass rather than stall the Hindu Code Bill, before the upcoming first general election might impede it altogether. Insisting that the Code's provisions did not in fact violate "dharmic" or "sacramental" Hindu marriage, as his fellow parliamentarian and, prior to independence, Savarkar's rival for the control of the Hindu

\footnotetext{
166“'The Constituent Assembly of India (Legislative): 'The Hindu Code, 1948) (As amended by the Select Committee)' (New Delhi: Govt. of India Press, 1949)," in "Assembly of India (Legislative) Select Committee on the Hindu Code Bill 1948: Report (Extract from Gazette of India, 21 August 1948)," IOR/V/26/100/19, India Office Records and Private Papers, British Library, London, 9. For the ambiguous conception of Hindu marriage as sacrament and contract, and for the uncertain success of fraud or force arguments to nullify or divorce marriage in postcolonial India, see Patricia Uberoi, "When Is a Marriage Not a Marriage? Sex, Sacrament and Contract in Hindu Marriage," Contributions to Indian Sociology 29/1-2 (1995), 319-45; S. Jaffer Hussain, "Hindu Marriage Act, 1955: Fraud as a Ground for Annulment," Journal of the Indian Law Institute 11/4 (1969), 520-34.

${ }^{167}$ See Butalia, The Other Side of Silence, 138.

168“"Legislative Assembly Debates, 1947 6th Assembly 3rd Session 3-18 February (Vol 1)," V/9/192, India Office Records and Private Papers, British Library, London, 216.

${ }^{169}$ See Newbigin, Hindu Family, 28-30; see also K. M. Kapadia, Marriage and Family in India, 3rd edn (Calcutta, 1972; first published 1955), 153-4.

${ }^{170}$ Gour, The Hindu Code, xxiii.
} 
Mahasabha, Dr Syama Prasad Mookerjee (1901-53), alleged, Gadgil argued somewhat cheekily,

There [in the Hindu Code] is free scope from the Dhushyanta Shakuntala type of marriage to Prithviraj Samyugita type of marriage, namely from Gandharva to the Rakshasa type and all the eight forms can be practised by any Member of this House or by the public outside. This Code does not prevent lovemaking, it does not prevent eloping with bride's consent even against the consent of the parents. So far as eight forms of Hindu sacramental marriage are concerned, they are not affected in the least. ${ }^{171}$

Shakuntala and King Dushyanta, and Princess Samyukta and King Prithviraj were among the most famous lovers in India's literary tradition. For Gadgil, rakshasa was simply an elopement.

Unlike politicians seeking to legalize deviant love, Savarkar did not conflate rakshasa marriage with consensual love where there could be none because there must be none: between communities designated as enemies. In 1878, John Mayne already defined the difference between gandharva and rakshasa marriage as one of social context. The former marriage was only possible in "a society in which a friendly, though perhaps stealthy, intercourse was possible between man and woman before their union, and in which the inclinations of the female were consulted." 172 This assumed (the potential of) friendship between families. Bankim agreed: a harana accorded with dharma only where the captor could eventually be reabsorbed into the girl's family, as was the case with Subhadra and Arjuna. ${ }^{173}$ For Bankim, the true enemy remained beyond the pale of harana. Savarkar weaponized harana to cross the pale. What makes Savarkar unique as a modern theorist of rakshasa marriage is that he espoused it in all its violence, thus ending the long history of its ambiguous slippage into gandharva marriage which, in Savarkar's own time, even fueled a romance genre of intercommunal "abductions." 174 This most unexpected champion of intercommunal marriage, Savarkar, did not mean love.

\section{Conclusion}

Through rakshasa marriage, Indian thought makes explicit what remains buried in the Western tradition: that the conjugal, rather than paternal, relation may be the foundational political relation. ${ }^{175}$ Recall that in India, it was the private sphere of women and the home that was the site of a struggle for sovereign control between colonizer and colonized elites. The irrepressible rakshasa marriage broadens our understanding of the strategies that Hindu elites adopted to become sovereign

\footnotetext{
171“Parliamentary Debates: (Part II: Proceedings Other Than Questions)," Official Report, vol. 15, Fourth Session of the Parliament of India 1951, 18 September 1951, Parliament of India Digital Library, 2759.

${ }^{172}$ Mayne, A Treatise on Hindu Law, 66.

${ }^{173}$ Chatterjee, Krishna-Charitra, 204.

${ }^{174}$ For the abduction romance see Pradip Kumar Datta, Heterogeneities: Identity Formations in Modern India (New Delhi, 2010), 155-213; Pradip Kumar Datta, Carving Blocs: Communal Ideology in Early Twentieth-Century Bengal (Oxford, 1999), 148-237; Gupta, Sexuality, Obscenity, Community, 241.

${ }^{175}$ See Becker, Gendering the Renaissance, 179, 188.
} 
beyond idealizations of Hindu conjugality past or present. ${ }^{176}$ Hindutva's founding father Vinayak Savarkar's espousal of rakshasa marriage in particular challenges the view that Hindu nationalism ultimately made the less disputed, chaste mother (land)-son and sister-brother relationship and the obligation to protection they invoked its ideological focal point. ${ }^{177}$ Rapes and abductions were not incidental to Hindutva. Rakshasa marriage served as theoretical preparation for the kind of action that was required but only moral during the exception of civil war. Whether the concept consciously played on the minds of Partition-time perpetrators is a question beyond the scope of this intellectual history.

After normalcy was restored, there also ended the need for Kshatriya morality. After 1947, Hindu nationalism regrouped around the figure of the Brahmin, the upholder of righteousness. The treatment of rakshasa marriage by K. M. Munshi (1887-1971), a writer-politician who was Savarkar's erstwhile ally in trying to prevent Pakistan and became a major theorist of post-independent Hindutva, is a case in point. Krishnavatara, Munshi's eight-volume life story of Krishna, is about the restoration of dharma after a time of moral degeneracy that becomes a metaphor for the Partition and Indian independence under Congress rule. ${ }^{178}$ The story frames rakshasa marriage as that which the uncivilized did. It meant "treating [a woman] as a Rakshasi," it was "prevalent [only] among the Rakshasas," and it constituted an offense against "Arya Dharma." 179 It was most certainly not a permissible marriage for Kshatriyas. But even Krishna's own gandharva marriage with Rukmini, which Manu allowed his caste, ${ }^{180}$ produces moral problems for Munshi's brooding Krishna: "Was that Dharma?" if it had caused pain to Rukmini's kin and made her an outcast? ${ }^{181}$ In Munshi's retelling, Krishna's purpose on earth is to vindicate dharma after its many abuses by Kshatriya kings, including in matters of marriage. ${ }^{182}$ Finally, in perhaps the most popular modern retelling of Arjuna's abduction of Subhadra, B. R. Chopra's iconic Hindi television serial Mahabharata (1988-90), rakshasa marriage again morphed into a consensual, though patriarchy-defying, love marriage. To prove that Subhadra went willingly with Arjuna, Krishna's on-screen version even advises his friend to let his sister

\footnotetext{
${ }^{176}$ See Tanika Sarkar, Hindu Wife, Hindu Nation: Community, Religion, and Cultural Nationalism (New Delhi, 2001), 41; Mrinalini Sinha, Specters of Mother India: The Global Restructuring of an Empire (Durham, 2006), 55; Chakravarti, "Whatever Happened to the Vedic Dasi?", 43; see also Mytheli Sreenivas, Wives, Widows and Concubines: The Conjugal Family Ideal in Colonial India (Bloomington, 2008), 77; Charu Gupta, "Anxious Hindu Masculinities in Colonial North India: 'Shuddhi' and 'Sangathan' Movements," CrossCurrents 61/4 (2001), 441-56, at 447-8.

${ }^{177}$ Cf., for example, Sarkar, Hindu Wife, 40, 50-51; Datta, "Abductions," 71-2; Gyanendra Pandey, "Hindus and Others: The Militant Hindu Construction," Economic and Political Weekly 26/52 (1991), 3003-4; Charu Gupta, "The Icon of Mother in Late Colonial North India: 'Bharat Mata,' 'Matri Bhasha' and 'Gau Mata'," Economic and Political Weekly 36/45 (2001), 4291-9. For women's role in the reproduction of Hindutva ideology see Urvashi Butalia and Tanika Sarkar, eds., Women and the Hindu Right: A Collection of Essays (New Delhi, 1995).

${ }^{178}$ Kanhaiyalal Maneklal Munshi, Krishnavatara, 8 vols. (Bombay, 1962-73). See especially the obvious allusions to gendered Partition violence in vol. 6, The Book of Vyaasa, the Master (Bombay, 1971), 34, 70.

${ }^{179}$ Munshi, Krishnavatara, 3: 275, 275 n. 1.

${ }^{180}$ Ibid., 3: 275n1.

${ }^{181}$ Ibid., 3: 215.

${ }^{182}$ Ibid., 2: 332, 342.
} 
steer the carriage that carries both away, saying, "This is not your journey; it is hers." 183 This was a story fit for modern Indian women.

In 1923, the monthly journal of the Women's Indian Association, Stri Dharma, featured an article that revealed slavery as the "essence of primitive marriage" and the hidden truth behind the ideal of the "womanly woman" used to counter woman's suffrage in India. ${ }^{184}$ The author was Lotika Ghose, a bachelor's degree holder who had recently made a "spirited defence" of women's suffrage, and the niece of the revolutionary-turned-yogi Sri Aurobindo and daughter of poet Manmohan Ghose. ${ }^{185}$ She charged, "Under this beautiful motto [of the womanly woman] we faintly see wife-capture and wife-purchase and the institution of serfdom from captives in war which began and went hand in hand with the institution of marriage."186 Arguing that slavery, though it had allowed Hellas and Rome to flourish, had since then exhausted its merits and was now replaced by the new Western standards of democracy and capitalism, Ghose rejected the old form of marriage that was slavery's outgrowth. She advocated a new form of companionate marriage between equal partners who equally divided their labour. ${ }^{187}$ As "man" had evolved from the narrow "selfishness" of the family, clan, and tribe to a greater national or commonwealth ideal, it was now for woman to likewise leave the "narrow domestic sphere" and march out into the world, in service of the nation. ${ }^{188}$ Historian Mrinalini Sinha's history of the event that launched the abstract category of "Indian woman," the publication of Katherine Mayo's Mother India in 1927, has described the specific antinomy of Indian feminism as that of an "agonistic liberal universalism." ${ }^{189}$ In addition to the liberal paradox of women's simultaneous equality with and difference to men that is characteristic of all feminisms, Indian feminism from its inception charged Indian women with being model Indian citizens to bridge the widening gap between Hindus and Muslims. This "double burden" ultimately proved untenable as Indian feminism, too, fractured along communal lines. ${ }^{190}$ Similarly, the trope of rakshasa marriage was only ever superficially about abstract "women," and really about groups of women as specific as enemies.

The purpose of Lotika's inclusion at this point is not simply to give voice to women-a valuable concern though this is, it should not curtail the gender question in the history of political thought. Rather, my purpose is to point, by way of a conclusion, towards the past and present global cross-fertilization between feminism and patriarchal theorizing. ${ }^{191}$ The resulting unprecedented foregrounding of rape in tackling the ancient problem of power in political thought found in India both its archive and its laboratory. The universalization of their marriage traditions

\footnotetext{
${ }^{183}$ Mahabharata (television serial, 1988-90), Episode 40: "Yah yatra tumhari nahin, uski hai."

${ }^{184}$ Lotika Ghose, "The Ideal of Womanhood," Stri Dharma: Official Organ of the Women's Association 6/ 10 (1923), 147-8.

${ }^{185}$ Ibid., 147.

${ }^{186}$ Ibid.

${ }^{187}$ Ibid.

${ }^{188}$ Ibid., 148.

${ }^{189}$ Sinha, Mother India, 200.

${ }^{190}$ Ibid., 201.

${ }^{191}$ See Coward, Patriarchal Precedents, 10-12. For a modern case in point see Kate Millett, Sexual Politics (Urbana, 2000), 110-15.
} 
both embarrassed and presented new possibilities for Indians that endure in political thought, popular tradition, and the law. This history is not straightforwardly a history of sexuality. Rather, my reconstruction of rakshasa marriage as a subject of political thought returns to the "symbolics of blood" (of kinship, fathers, death), which Foucault's history of sexuality already presumes superseded by "an analytics of sexuality" (deviancy, populations, life) in modern times. ${ }^{192}$ But this return is not straightforward. Instead, the history of rakshasa marriage in modern Indian political thought attacks sovereignty as derived from what Foucault aptly called the "Sovereign-Father" of classical Western political theory. ${ }^{193}$ What I have sought to uncover is a discourse of power and indeed sovereignty that not only made its foundation in gendered, potentially reproductive violence explicit, but also established itself through the "other" rather than one's "own" women, by breaking the patriarchal hold of its rivals. An offense to fathers heralded by Vinayak Savarkar, the miscegenous discourse of rakshasa emerged as the matrix for Hindutva in its war against the Indian Muslim potentiality of sovereignty. In this sense, Hindutva then and now produced its own mirror image as the feared Muslim "love jihad."

Acknowledgments. I am thankful to Shruti Kapila, Taushif Kara, Samuel Garrett Zeitlin, Salmoli Choudhuri and Shuvatri Dasgupta for their generous feedback, inspiration, and conversation. An earlier version of this article was presented at the Political Thought and Intellectual History Women's Lunch Seminar, University of Cambridge, in December 2020. The article is much improved by the participants' comments and that of its two anonymous reviewers. A special thanks to Tracie M. Matysik and the editorial team at Modern Intellectual History.

\footnotetext{
${ }^{192}$ John Borneman, "Until Death Do Us Part: Marriage/Death in Anthropological Discourse," American Ethnologist 23/2 (1996), 215-35, at 216.

${ }^{193}$ Michel Foucault, The History of Sexuality, vol. 1, An Introduction, trans. Robert Hurley (New York, 1978; first published 1976), 150.
}

Cite this article: Sabastian L (2022). Women, Violence, Sovereignty: "Rakshasa" Marriage by Capture in Modern Indian Political Thought. Modern Intellectual History 19, 757-782. https://doi.org/10.1017/ S1479244321000391 